\title{
Implementation of Regional Head Elections in DKI Jakarta in 2017
}

\author{
Debora Adeleida ${ }^{1}$, Retnowati Wahyuning Dyas Tuti ${ }^{2}$ \\ \{debraledeida@gmail.com ${ }^{1}$, retnowatiwdtuti@yahoo.com ${ }^{2}$ \} \\ Universitas Muhammadiyah Jakarta, Indonesia ${ }^{1,2}$
}

\begin{abstract}
Elections are a tool for conducting political education for citizens so that they understand their rights and obligations. In general, the purpose of general elections is to enable the transfer of government in an orderly and secure manner, to exercise popular sovereignty, and in the context of exercising the rights of citizens. The purpose of this study was to determine the Implementation of Regional Head Elections in DKI Jakarta in 2017. This study uses theories from Edward III and uses descriptive research methods with a qualitative approach. Data was collected by way of interviews, observation, and documentation. Data analysis uses the Analysis Model of Miles and Huberman. Test the validity of the data in this study by using triangulation. The results of this study indicate that the Implementation of Regional Head Elections in DKI Jakarta in 2017 went well, seen from the four indicators in Edward III's theory.
\end{abstract}

Keywords: Implementation, Election, Regional Head.

\section{Introduction}

Indonesia is a democratic country, where the people as the highest authority in a country. Democracy is a form or mechanism of a country's government system as an effort to realize the sovereignty of the people (citizen power) over the country to be run by the country's government. In practice, technically, the exercise of people's sovereignty is an executive government directly elected by the people and people's representatives in the people's representative institutions or parliament. The representatives of the people who act for and on behalf of the people, who politically determine the style and manner of operation of the government, as well as the objectives to be achieved both in the long term and short term [1][2]. In order for the people's representatives to act on behalf of the people, the people's representatives must be determined by the people themselves.

Elections are a tool for conducting political education for citizens so that they understand their rights and obligations. With the general election, the people can realize their aspirations which are channeled through political parties. In general, the purpose of general elections is to enable the transfer of government in an orderly and secure manner, to exercise popular sovereignty, and in the context of exercising the rights of citizens.

The 2017 DKI Jakarta Governor Election will be held on 15 February 2017 and 19 April 2017 to determine the Governor and Deputy Governor of DKI Jakarta for the 2017-2022 period. This is the third regional head election for Jakarta which is carried out directly using the voting system. This period election schedule was advanced from the previous period's 
election schedule, which was July 11 because it followed the second wave of the Simultaneous Regional Election schedule in 2017.

Based on regulations, only political parties that have 22 or more seats in the Jakarta DPRD can nominate candidates. Political parties that have less seats can nominate candidates only if they have gained support from political parties.

The Directorate General of Regional Autonomy of Sumarsono said, from the implementation of the 2017 elections in 101 regions on 15 February, only the DKI Regional Election was the most problematic in relation to the Permanent Voter List (DPT).

The Acting Governor (PLT) of DKI Jakarta Governor said, the cause was that Jakarta was the closest and seen city and became a concern. Overall, the first round of the 2017 DKI Pilkada has three main issues.

First, Sumarsono said, it was a matter of the DPT. There are still around 56 thousand residents who have not done electronic recording of electronic Resident Identity Cards or EKTPs.

"The three main issues, firstly, that there are around 56 thousand who have not recorded, are sought not to meet the person. Indeed, because some are in apartments or in locations that have been displaced," said Soni at the Parliament Complex Senayan Jakarta, Tuesday (7/3/2017).

According to Sumarsono, his party continued to pursue the people who had moved or were displaced. In fact, there are cars around to record their data.

"This chase continues, until there is a car around to pick who wants to record. Though once recorded, yet we give the E-KTP hardcopy of it, but we love information suket (mail information) for the benefit of the elections. It was not 100 percent well the recording", he explained.

The second problem, said Sumarsono, DKI 2017 Regional Election was very encouraging because the level of participation was very high. In fact, to the lack of ballots in several polling stations (TPS).

"Secondly, unexpectedly, DKI Election is encouraging. It turned out to be able to provoke extraordinary participation, target 75 , an increase of 78 percent (almost) in all polling stations," he said.

"So, it is also not accommodated, the form (additional DPT) runs out. This is the second problem, this is unexpected, huh," said the man who is familiarly called Soni.

The third problem, Sumarsono revealed, was a small problem. Like voters who cast their ballots at other polling stations (TPS). However, he promised that these problems could be overcome.

"In TPS A, vote for TPS B, then bring E-KTP, but don't bring $K K$, that's a lot. God willing, this third point, how to finish everything one step according to the mandate, from the Minister of Home Affairs to me as PLT Governor," he said. 
According to George Edward III in Abdullah and Ramdhani [3] there are 4 factors that influence the success or failure of a policy implementation. 4 factors include: communication factors, resources, disposition and bureaucratic structure. And the following explanation:

a) Communication

According to Edward III in Abdullah and Ramdhani [3], communication is defined as the process of delivering communication of tor information to the communicant. Information regarding public policy according to Edward III needs to be conveyed to the policy makers so that the policy actors can know what they have to prepare and do to carry out the policy so that the goals and objectives of the policy can be achieved as expected [4]. According to Edward III policy communication has several dimensions, including dimensions of transmission, clarity and consistency.

- The transmission dimension requires that public policies be conveyed not only to the policy implementers, but also to the policy target groups and other interested parties, both directly and indirectly.

- The dimension of clarity requires that the policies transmitted to the target group implementers and other interested parties be clear, so that between them know what is the purpose, goals, objectives, and substance of public policy so that each will know what must be prepared and implemented to succeed the policy.

- The dimension of consistency is needed so that the policies taken are not confusing, thus confusing policy implementers, target groups and interested parties.

b) Resource

Edward III in Abdullah and Ramdhani [3] revealed that resource factors have an important role in policy implementation. These resources include human resources, budget resources, equipment resources, authority resources.

- Human Resources: one of the variables that influences the successful implementation of policies.

- Budget Resources: the limited budget available causes the quality of services that should be provided to the community available to be limited.

- Equipment Resources: facilities used for the operational implementation of a policy which includes buildings, land and facilities relating to ease in providing services.

- Authority Resources: sufficient authority to make its own decisions owned by an institution will influence the institution in implementing a policy.

c) Disposition

According to Edward III in Abdullah and Ramdhani [3] is the willingness, desire and tendency of policy makers to implement the policy seriously so that what is the goal of the policy can be realized. If the implementation of the policy wants to be effective and efficient, the implementers not only know what needs to be done and have the ability to carry out the policy, but they must also have the will to implement the policy. Following are the factors that concern Edward III regarding policy implementation, including:

- Appointment of bureaucracy: the attitude of the implementers will cause real obstacles to the implementation of the policy, if there are personnel who do not implement the policies desired by officials whose position is higher. Therefore, the appointment and selection of personnel implementing the policy must be people who have dedication to the policies that have been set. 
- Incentives: one of the techniques suggested to overcome the problem of the attitude of policy implementers by manipulating incentives.

d) Bureaucratic Structure

According to Edward III in Abdullah and Ramdhani [3] there are two characteristics in the bureaucratic structure, namely standard operation procedure and fragmentation.

\section{Methodology}

This study uses descriptive research with a qualitative approach and data collection techniques using the following techniques: interviews, observation, documentation and focus group discussion. The technique for selecting informants will be using purposive sampling technique. Data analysis techniques used in this study refer to the concept of Miles \& Huberman [5], namely: Data reduction, data exposure, conclusion drawing and verification. While the data validity test uses triangulation.

\section{Discussion}

In the implementation of the Implementation of Regional Head Elections in DKI Jakarta in 2017 it uses a theory from Edward III whose indicators consist of 4 namely:

a) Communication

- Transmission Dimension: in this case the DKI Jakarta Election Commission provides information related to the DKI Jakarta post-conflict local election in 2017, but there are still people who have not yet received the information.

- Dimension Clarity: giving or socializing it to the implementers of the policy, even to the target to be addressed [6].

- Consistency Dimension: in this case the Jakarta Election Commission is very consistent, especially to prevent confusion and to reach the target group of interest.

b) Resource

- Human Resources: DKI Jakarta Election Commission has a lot of human resources that have been given prior socialization so that the elections in 2017 run well, in addition to the Election Commission also assisted by Bawaslu in terms of supervision in the implementation of the elections.

- Budget Resources: DKI Jakarta itself has a budget in terms of holding regional head elections, and all of that is used to make the election successful, starting from fulfilling socialization materials and other attributes.

- Equipment Resources: in this case the equipment in the 2017 general election of DKI Jakarta regional heads will be fulfilled, starting from ballot boxes and election papers. And all other needs that are needed in the post-conflict local election.

- Authority Resources: in this case the Chairperson of the DKI Jakarta KPUD has his own authority to regulate all forms of the implementation of the DKI Jakarta post-conflict local election by referring to the applicable laws and regulations. 
c) Disposition

- Appointment of Bureaucracy: bureaucratic actors in the implementation of the DKI Jakarta post-conflict local election are deemed sufficiently dedicated in implementing policies that have been previously determined and prioritizing the needs of the community.

- Incentives: bureaucrats involved in the implementation of post-conflict local election policies in 2017 do not include groups or individuals who manipulate incentives carried out to meet their personal or organizational interests.

d) Bureaucratic Structure

In the implementation of the post-conflict local election, DKI Jakarta has regulations that have been made by the policy holders and the Chairperson of the DKI Jakarta $K P U D$ only carries out the assigned tasks and standard operational procedures.

\section{Conclusion}

Based on the results of research discussions according to the theory of Edward III, it can be concluded that the implementation of Regional Head Elections in DKI Jakarta in 2017 went well even though in reality communication indicators were still not going well, and in terms of public participation also rose in the second round of the general election compared to the first round, but all that cannot be separated from the success of the Jakarta Election Commission in creating an atmosphere of regional elections that is peaceful, safe and remains conducive.

\subsection{Suggestion}

In the implementation of the Regional Head Election in DKI Jakarta in 2017 it has been going well, but there is still a hoax news that dropped the election candidate, and this is where the role of government is needed to minimize the hoax news which will soon be trusted by the public. And also needed public trust in the holders and implementers of policies in carrying out their respective duties.

\section{References}

[1] D. R. Nugroho, "Public Policy: formulation, implementation and evaluation," PT Elex Media Komputindo Jakarta, 2003.

[2] P. A. Sabatier, "Top-down and bottom-up approaches to implementation research: a critical analysis and suggested synthesis," J. Public Policy, vol. 6, no. 1, pp. 21-48, 1986.

[3] A. Ramdhani and M. A. Ramdhani, "Konsep umum pelaksanaan kebijakan publik," J. Publik, vol. 11, no. 1, pp. 1-12, 2017.

[4] I. Nawawi, "Public Policy Analisis," Strateg. Advokasi Teor. dan Prakt., 2009.

[5] M. B. Miles, A. M. Huberman, M. A. Huberman, and M. Huberman, Qualitative data analysis: An expanded sourcebook. sage, 1994.

[6] R. Nakamura and F. Smallwood, "The Policy Implementation,” New York St. Martin's, pp. 12 18,1980 